\title{
ECONOMETRIC COMPARISON OF REGRESSION DEPENDENCIES BETWEEN PRODUCTION AND ITS INNOVATION EXPENDITURES IN POLISH INDUSTRIES
}

\author{
Jan ZWOLAK \\ Faculty of Economies and Finance, Kazimierz Pulaski University of Technology \\ and Humanities in Radom, Poland
}

Received 12. February 2020, Reviewed 25. March 2020, Accepted 02. May 2020

\begin{abstract}
The achieved results have shown an increase in flexibility of innovative sold production within the periods studied in terms of real capital $(0.456,0.518$ and 0.628 respectively), and a decrease in its flexibility with respect to human capital $(0.377,0.234$ and 0.270 respectively). Innovations were mainly carried out by means of a passive transfer of technology, such as by the introduction of new machinery and equipment, as well as computer programming implemented within the Polish industry. Flexibility of the innovation rate in relation to human capital may be equal to unity. In relation to this potential flexibility, human capital is used in the abovespecified periods in $37.7 \%, 23.4 \%$, and $27 \%$ within the Polish industry. The overall efficiency parameters of the processes of sold production of new goods and those which have been significantly improved (second terms) with respect to the expenditure streams of real and human capital in the above periods decrease with time. This indicates a decrease in the efficiency of these capitals.
\end{abstract}

Key words: Physical capital, human capital, asymmetry, Cobb-Douglas function, technology transfer, flexibility.

JEL Classification: O32, O44, R58

\section{Introduction}

Each and every country requires innovation to build its competitive position and national income within the framework of the global economy; it increases the efficiency of investments based on innovation (Grillo et al. 2011). Innovative systems emphasise the impact of interactions, including the building of an innovative infrastructure. Regionalisation based on development centres is representative of the strength of globalisation processes (Lundvall 2010). The processes of formation and implementation of innovation are multi-stage, and as such, they are accompanied by complexity. One may, therefore, speak of a regional innovation paradox constituted by the relationship between a region with a lower potential for innovation and a region forming the basis for the development of active innovations (Skokan 2010). There can also be a small share in the structure of innovation expenditures for research and development which results from the application of low technology (Huang et al. 
2010), while these expenditures are consequent to the substitution of technological cooperation with other business entities.

The aim of the study is to identify the regression dependencies between the innovative production sold and the real and human capital in the years 20052007, 2008-2010 and 2011-2013. Moreover an indication of changes in the shaping of the fluctuation of innovative production sold in the Polish industry over the studied period.

The basis for the study was the hypothesis that there is an imbalance (asymmetry) of real capital in relation to human capital in shaping the sold innovative production in Polish industry in the years 2005-2013.

Section 2 contains a review literature. Section 3 presents the material and methods of the conducted studies. Section 4 presents the characteristics of data sets. Section 5 results and debate. Conclusions are presented in the final section.

\section{Literature review}

The EU statistics present data that are pre-processed and unsuitable for the determination of the regressive dependence of the sold innovative production on real innovative capital and human capital. And when they are already used in studies they show the relationship of linear regression, due to their averaging.

Enterprises have to seek new ways (methods) to keep up with the competition and the rapidly increasing pace of change (Stejskal \& Hájek 2015; Tlesova, Mergaliyeva, Sultanguzhiyeva, \& Sharafutdinova 2018). Numerous modern studies confirm the relationship between the increase in regional competition and the increase in knowledge resources (Audretsch, Hülsbeck \& Lechmann 2012; Kwiek 2012; Hudáková, Fil'a \& Maroš, 2017). The increasing level of knowledge resources continues to be a new source of economic growth (Snieška \& Bruneckiene 2009). Knowledge as the enterprise's resource is the source of the implementation of the human and intellectual capital of enterprises, regions and the country (Prokop, Stejskal \& Kuvikova 2017). Innovative customer-orientation is also mediated by innovative technologies (Karatepe, Uner \& Kocak 2016). The mediation of their knowledge and exploitation ability allows the competitors to achieve sustainable benefits (Kim, Basa, Naidu \& Cavusgil 2011; Apaydın, 2018). This competition takes place between the micro and macro level (Kaufmann, Tsangari \& Vrontis 2012). Also, strong relations among the enterprise's shareholders may be conducive to new ideas for the implementation of innovations (Gellynck, Kahne \& Weaver 2010; Stojčić, Hashi \& Aralica 2018).

The measure of the level of the enterprise's intellectual capital is the difference between the enterprise's present market value (number of shares multiplied by their current market value) less its book value. In turn, as pointed out by Labunska, Petrova \& Prokopishyna (2017), it is not enough to purchase innovative assets and combine them into a business. They need to be combined with research and development expenditure $(R \& D)$ that does not lead to the creation of tangible, but intangible assets as the innovation expenditure of a given period. In the process of innovation this means linking the unique information resources that may create the interdependence relationships with a novel product or bring the effect of innovative activity. Such innovative activity is an intentional innovative action, a process and a constant basis (Cammarano, Caputo, Lamberti \& Michelino 2017; Koval'ová, Hvolková, Klement \& Klementová 2018). 
A customer oriented at high technological and innovative abilities is present in foreign markets (Cavusgil, Knight \& Uner 2011). This is also being confirmed by theoretical and empirical studies (Melen \& Nordman 2009; Freeman, Hutchings, Lazaris \& Zyngier 2010; Gorlevskaya, Kubičková, Fodranová \& Žák 2018). Highly technical, innovative enterprises locate their businesses in highly competitive regions, where the level of productivity and innovations is high (Annoni \& Kozovska 2010). New, economically useful knowledge that leads to product innovation and/or process innovation or marketing innovation results in economic growth and regional development (Lee, Olson \& Trimi 2012).

The modern literature proves that currently the role of knowledge resources in the process of increase in creating innovation is growing (Connell \& Ranjit 2013). The role of knowledge as the human capital impacting the relative gain in sold innovative production in the enterprises and regions of Polish industry has also been taken into account in the studies conducted herein. Greve (2007) proposed to study innovation as the existing implementation of knowledge (human capital) and (sold innovative) products. Such relations of innovation are the basis of the studies contained in this paper. Moreover, the studies attempt at determining the extent to which the sold innovative production of Polish industry is based on knowledge (human capital) (Kitson, Martin \& Tyler 2004).

\section{Material and Methods}

The exemplification part of the study is based on the regional (voivodeshiprelated) set of empirical data that were brought down to the constant prices of the year 2005. This allowed to study the function parameters and to compare them over time. It turns out that in terms of research, the mechanism of technological progress and innovation is crucial for the applicable methodology. Related to it is the length of the time horizon of the study. As indicated by Pianta (2001, p. 143). Consequently, the processes of both real and human capital formation require a long-term approach. The supply of innovation at a specific market value depends on the size of the market investment. Therefore, with a specific need for change, it turns into a cost regression. Moreover, the research is also carried out in a three-year framework of the entire study period, in accordance with the accepted standards of methodological research on innovations implemented in OECD countries.

The selection of explanatory variables was made with the help of the matrix of logarithm correlation coefficients at the significance level of $p<0.05$, where $N=48$.

The following variables have been preliminarily adopted:

$Y$ - the value of sold production of new and significantly improved goods,

$x_{1}$ - expenditures (value) for research and development activities,

$x_{2}$ - expenditures (value) for knowledge from external sources and software,

$x_{3}$ - expenditures (value) for buildings and land,

$x_{4}$-expenditures (value) for machines, technical equipment, tools and means of transport,

$\varepsilon-$ random component.

Research conducted over a long time horizon shows curvilinear dependencies. We have, therefore, selected the Cobb-Douglas production function (a curvilinear power function):

$$
Y=a x_{1}^{b} x_{2}^{c} x_{3}^{d} x_{5}^{f} \varepsilon
$$




$$
\begin{array}{ll}
Y=a x_{1}^{b} x_{2}^{c} x_{5}^{f} \varepsilon & \text { where: } x_{5}=x_{2}+x_{4} \\
\text { or: } Y=a x_{3}^{d} x_{4}^{\theta} x_{6}^{g} \varepsilon & \text { where: } x_{6}=x_{1}+x_{2} \\
\text { or: } Y=a x_{4}^{b} x_{6}^{g} \varepsilon &
\end{array}
$$

In equation (1), due to the decomposition of the defined expenditures (values) on the fluxes of human and real capital, the correlation of a subset of variables is insignificant. Based on the matrix of logarithm correlation coefficients with their significance of $\mathrm{p}<0.05$.

On the other hand, in equation (2), the variables $x 3$ and $x 4$ are not correlated, although they are identical, while the variable $x 6$, composed of variables ( $x 3$ and $\times 4$ ) performs similar functions and their composition does not significantly increase the parameter, nor the correlation or the multicolinearity of these variables. The change in the definition of the variables is also contained in the equation (3). A redefinition of the explanatory variables is aimed to maintain their interpretative sense. Even if the variables are not correlated and when they are correlated, then the determination of their parameters may be associated with a similar standard error (Maddala 2001).

The combination of defining variables (expenditures) while maintaining the interpretation in the economic sense can reduce the colinearity which distorts the statistical inference. In order to preserve the similarity of functions, the ultimate combination of variables definition has been brought down to the mobile streams of real (x4) and human (x6) capital - equation (4).

The study of the randomness of distribution of the random component was conducted by means of a graphical analysis, which confirmed the verification of the hypothesis about the accuracy of the chosen form of the analytical function model (Table 2).. The application of tests for estimates significance of parameters of multiple regression model has been shown by Maddala 2001.

The mutual correlation of variables $x 4$ and $\times 6(\mathrm{r})$ does not pose a problem as it does not exceed the overall level of multiple correlation (R) (2005-2007, 0.809, 0.825; 20082010, 0.708, 0.721; 2011-2013, 0.706, 0.806) (Klein 1962, p. 101).

\section{Statistical characteristics of the studied sets}

The study was conducted based on empirical data sets of all provinces in Poland from the years 2005-2007, 2008-2010 and 2011-2013. Data sets from these periods are comparable because they have been expressed in fixed prices from 2005, while the number of elements in each set is $\mathrm{N}=48$. The statistical characteristics of the features of the variables have been shown in Table 1.

One of the classic measurements of the breakdown of an empirical data set is the arithmetic mean (Table 1). A change of any value in the data set brings about a change in the arithmetic mean value. The data mean summarises all the information contained in the set. The mean value of production sold in the examined period decreases with time. This indicates that what also changes is the range of the feature value in the sets studied. The result is that with the decreasing arithmetic mean of sold production of new and significantly improved goods, the gap gets reduced. In turn, this means that the volatility of the value of production in the examined sets and years also decreases. 
Table 1. Features variables (prices as of 2005)

\begin{tabular}{|c|c|c|c|c|c|c|c|}
\hline Item & Specification & Years & $\begin{array}{l}\text { Unit of } \\
\text { measure }\end{array}$ & Symbol & $\begin{array}{c}\text { Arithmetic } \\
\text { mean }\end{array}$ & $\begin{array}{c}\text { Range } \\
\text { min. - } \\
\text { max. }\end{array}$ & $\begin{array}{c}\mathrm{CV} \\
\%\end{array}$ \\
\hline 1. & $\begin{array}{l}\text { Sold production } \\
\text { of new and } \\
\text { significantly } \\
\text { improved }\end{array}$ & $\begin{array}{c}2005- \\
2007 \\
2008- \\
2010 \\
2011- \\
2013\end{array}$ & $\begin{array}{l}\text { million } \\
\text { PLN }\end{array}$ & Y & $\begin{array}{l}8319,2 \\
7373,6 \\
7156,0\end{array}$ & $\begin{array}{c}670,7- \\
47343,7 \\
788,6- \\
32070,5 \\
629,3- \\
28920,3\end{array}$ & $\begin{array}{l}131,8 \\
108,4 \\
112,9\end{array}$ \\
\hline 2. & $\begin{array}{l}\text { Expenditures } \\
\text { (value) for } \\
\text { machinery, } \\
\text { technical } \\
\text { equipment, tools } \\
\text { and means of } \\
\text { transport }\end{array}$ & $\begin{array}{c}2005- \\
2007 \\
2008- \\
2010 \\
2011- \\
2013\end{array}$ & $\begin{array}{l}\text { million } \\
\text { PLN }\end{array}$ & $\mathrm{x}_{4}$ & $\begin{array}{l}263,2 \\
582,8 \\
721,0\end{array}$ & $\begin{array}{c}29,5- \\
1772,6 \\
62,5- \\
2874,2 \\
44,8- \\
2877,7\end{array}$ & $\begin{array}{l}131,8 \\
101,9 \\
100,0\end{array}$ \\
\hline 3. & $\begin{array}{l}\text { Expenditures } \\
\text { (value) for } \\
\text { research and } \\
\text { development } \\
\text { activities and } \\
\text { knowledge from } \\
\text { external sources } \\
\text { and software }\end{array}$ & $\begin{array}{c}2005- \\
2007 \\
2008- \\
2010 \\
2011- \\
2013\end{array}$ & $\begin{array}{l}\text { million } \\
\text { PLN }\end{array}$ & $x_{6}$ & $\begin{array}{l}117,1 \\
186,0 \\
301,2\end{array}$ & $\begin{array}{c}9,0-493,1 \\
2,7-1095,9 \\
18,0- \\
1722,6\end{array}$ & $\begin{array}{l}104,6 \\
134,6 \\
126,8\end{array}$ \\
\hline
\end{tabular}

The trend of the central value of the arithmetic mean of the expenditures (value) for machinery, technical equipment, tools and means of transport is growing. Also changing is the range of these expenditures, which means that the gap between them is also growing. It ought to be added that the gap between the sets in the years 2008-2010 and 2011-2013 is the same. This serves to explain that the internal variability (dispersion) of the characteristics of this explanatory variable was the same in all of the above-specified year periods. The largest internal variability of investment in machinery, technical equipment, tools and means of transport in the years 20052007 is the same as the internal variability of the value of innovative production sold during those years. It can be assumed that the mutual interaction of these variables could be important for their regression dependency.

The mean value of expenditures on research and development activities and on knowledge from external sources and software in the examined sets and years is also growing. The result is that research and development activities are costly and do not always render the expected results (Thomke \& von Hippel, 2002). This indicates a change within the range of value of the characteristics of these expenditures and an increase in the dispersion of the characteristics value within the set - an increase in the span between them. On the other hand, with an increase of the internal variability in the sets, also growing is the share of variation expressed with a variability coefficient within the examined sets and years over time. 


\section{Results and debate}

The innovative activity of the Polish industry is determined by the prevailing economic conditions. The impact of these conditions is contained in the empirical data expressed in 2005 prices which allow comparability of the estimated function parameters in the studied years and over time. Regression dependency between innovative production sold and streams of real and human capital in 2005-2007, 2008-2010 and 2011-2013 are contained in Table 2. The tabular notation included the Cobb-Douglas power regression equation with a statistical evaluation of the function parameters (Table 2). The above-specified aggregated variables ( $x 4$ and $x 6$ ) explain the variability of the sold production of new and significantly improved goods in Polish industry in $2005-2007$ at $68 \%$, in $2008-2010$ at $52 \%$ and at $65 \%$ in the years 2011 2013.

Table 2. Functions Cobb-Douglas

\begin{tabular}{|c|c|c|c|c|c|c|c|c|c|c|c|c|c|}
\hline \multirow{2}{*}{ ¿્ટ } & \multirow{2}{*}{$a^{*}$} & \multicolumn{2}{|c|}{$\begin{array}{l}\text { Regression } \\
\text { coefficient }\end{array}$} & \multicolumn{3}{|c|}{ Standard error } & \multicolumn{3}{|c|}{ T-Test } & \multicolumn{3}{|c|}{ significance level } & \multirow[t]{2}{*}{ R2 } \\
\hline & & $x_{4}$ & $x_{6}$ & a & $x_{4}$ & $x_{6}$ & $\mathrm{a}$ & $x_{4}$ & $x_{6}$ & $\mathrm{a}$ & $x_{4}$ & $x_{6}$ & \\
\hline $\begin{array}{l}2005- \\
2007\end{array}$ & 94,63 & 0,456 & 0,377 & 0,52 & 0,16 & 0,12 & 8,67 & 2,80 & 3,18 & 0,00 & 0,01 & 0,00 & 0,68 \\
\hline $\begin{array}{c}2008- \\
2010\end{array}$ & 70,60 & 0,518 & 0,234 & 0,87 & 0,21 & 0,11 & 4,90 & 2,47 & 1,81 & 0,00 & 0,02 & 0,05 & 0,52 \\
\hline $\begin{array}{c}2011- \\
2013\end{array}$ & 13,83 & 0,693 & 0,270 & 0,66 & 0,15 & 0,12 & 3,95 & 4,61 & 2,29 & 0,00 & 0,00 & 0,02 & 0,65 \\
\hline
\end{tabular}

Source: Own numerical calculations.

$a^{*}$ - dilogarithmed constant of the equation (second term).

They determine the regression dependency between the growth of expenditure and the increase in production. They are the elasticities of $Y$ with respect to $x 4$ and $x 6$, and according to the marginal theory of division developed by J. B. Clark, they constitute the shares of expenditure of these factors $(x 4$ and $\times 6)$ in the product (in sold production of new and significantly improved goods) (Solow 1956). These properties refer to the regression dependency.

These expenditures are responsible for the passive transfer of technology to enterprises of the industrial sector $(0.456,0.518$ and 0.628$)$ (Table 2). They also constitute the main expenditure of their innovation activity.

It stems from the weak tendency to introduce streams of human capital resulting from $\mathrm{R} \& \mathrm{D}$ cooperation and obtaining knowledge from external sources $(0.377,0.234$ and 0.270$)$ (Table 2). It should also be noted that higher innovation is followed by a parallel increase in all dimensions of innovation potential for its efficient use in industry. Parameters of overall efficiency of the processes of innovation production sold (second terms) with respect to investment flows for real and human capital, together with the period growth decrease over time. This indicates a decrease in the efficiency of the streams of expenditure on real and human capital in Polish industry in the years 2005-2013.

It must be noted, however, that the total flexibility of the studied innovative expenditures approaches unity, especially in the years 2011-2013, which means that 
this regression dependency is a homogeneous function, a function in which the input of factors and the production are growing by the same percentile point $(1 \%)$. An almost proportional increase in sold production of new and significantly improved goods resulting from a proportional increase in both expenditures of real and human capital indicates stable economies of scale. The problem, however, is that under certain technical conditions (in short periods there is no change when technology is given), an increase in the value of innovation (expenditure structure) remains in proportion to the increase in spending on human capital. Thus, the value of innovation depends mainly on the balance between the flows of human capital formation. In the innovation function the innovation growth rate is a dependent variable, and its modulus of elasticity in relation to tangible capital expenditures $(x 4)$ has a number lesser than one, which is how it should be. By contrast, the innovation growth rate flexibility in terms of human capital expenditure can be equal to unity. In terms of the recently indicated potential flexibility, human capital amounted to only $37.7 \%$ in $2005-2007$, to $23.4 \%$ in $2008-2010$ and in $2011-2013$ to $27 \%$. Therefore, there are very large potential application reserves of streams of human capital in Polish industry.

The regression of the years 2011-2013 is a function where the expenditure of factors and the effects are rising by almost the same percentage $(10 \%)$. Therefore, it is approaching a proportional increase in sold production of new and significantly improved goods in Polish industry. In the years 2005-2007, 2008-2010 and 2011-2013, and so in short periods of time, one can assume no change in the area of technology, which allows us to identify the role of human capital innovation against the background of the relative stability of real capital in Polish industry in the studied periods. The proportion of the impact (the sums of elasticity $=100 \%$ ) shows that the impact of spending on machinery, technical equipment, tools and means of transport in the years $2005-2007$ amounted to $54.7 \%$ in $2008-2010$ to $68.9 \%$, and in the years 2011 2013 to $72 \%$. In the studied years, the impact of expenditure on machinery, technical equipment, tools and means of transport on the relative increase of sold production of new and significantly improved goods was steadily growing, and in the years 2011-2013 it achieved more than two-thirds of total flexibility. At the same time, the impact of expenditures on R\&D activities and on knowledge from external sources and software in $2005-2007$ amounted to $45.3 \%$, in $2008-2010$ to $31.1 \%$, while in 2011 2013 , it amounted to $28 \%$. The impact of human capital on the relative increase in sold production of new and significantly improved goods showed a gradual decrease in the studied years, while in the period between 2011-2013, it amounted to less than one-third. This indicates a reduced role of innovation, especially regarding human capital in the Polish industrial enterprises over the studied period.

\section{Conclusions}

The studies have confirmed the hypothesis that there is an imbalance (asymmetry) of real capital in relation to human capital in shaping the sold innovative production in Polish industry in the years 2005-2013.

The resulting regression models have allowed us to explain the variability of sold production of new and significantly improved goods with respect to the real and human capital at a relatively constant level of other factors, which amounted to $68 \%$ in $2005-2007,52 \%$ in $2008-2010$ and $65 \%$ in $2011-2013$. Therefore, we have achieved a satisfactory explanation of the variability of innovative production sold by the above-specified capitals in the Polish industry in the years 2005-2013. 
The flexibility of sold production of new and significantly improved goods in the periods studied grows in time with respect to real capital $(0.456,0.518$ and $0.628)$, while it decreases in relation to human capital $(0.377,0.234$ and 0.270$)$. There was thus a profound imbalance in the implementation of human capital as opposed to real capital in Polish industry in the years 2005-2013. Innovations were mainly realised by the passive transfer of technologies to the Polish industry companies, such as new machinery, equipment and computer programming.

The participation of flexibility of the sold production of new and significantly improved goods was steadily declining with respect to human capital in the surveyed years. It is a consequence of the weak tendency to introduce streams of human capital resulting from $\mathrm{R} \& \mathrm{D}$ cooperation and the acquisition of knowledge from external sources. Moreover, not all dimensions of the innovation potential are taken advantage of, in terms of its effective use in Polish industry. This is confirmed by the overall efficiency parameters of the process of sold production of new and significantly improved goods in relation to the investment flows of real and human capital which have been shown to be in a decline. This is indicated by a decrease in the efficiency of those capitals in Polish industry over the studied years.

The problem of innovation in the Polish industry also lies in the fact that in the absence of equilibrium between the streams of human capital formation there are difficulties in obtaining a proportional increase of human capital in relation to the innovative production sold. This reduces the gain of constant economies of scale of innovative production sold, and therefore also the regression dependency described by a homogeneous function, in which the outlay of the factors and the effects are increasing by the same percentage.

Flexibility of innovation increase rate in relation to human capital can be equal to unity. Relative to this potential flexibility, human capital is implemented only in $37.7 \%(2005-2007)$, in $23.4 \%(2008-2010)$ and $27 \%$ (2011-2013) respectively. Its use accounts for more than a quarter of the potential for the Polish industry.

The conducted studies present a contribution to the current innovative knowledge. They fill a gap in the current literature on innovation and the determination of the dependence of the sold innovative production on aggregated streams of real innovative and human (intellectual) capital. The studies based on the empirical data of innovative variables and the Cobb-Douglas power function model constitute the formalized approach to the theory of innovation of the causal type (model $=$ theory). Furthermore, the studies have allowed the determination of to what extent the sold innovative production relies on knowledge, which is pointed out in the literature as not possible.

The lack of verification of empirical data for the year 2016, and more than a year of delay in their provision by the Central Statistical Office in Warsaw (Poland) prevents the inclusion of the years 2014-2016 in Polish industry in the studies.

Further studies will be conducted with the aim of determining the effectiveness of innovations with the help of the categories of average production and marginal productivity of real innovative capital and human capital in Polish industry.

\section{Bibliography}

1. Annoni, P., \& Kozovska, K. (2010). EU Regional Competitiveness Index. Luxembourg: Publication Office of the European Union.

2. Apaydın, Ş. (2018). Entrepreneurship, innovation and business cycles in Turkey. Journal of Applied Economic Sciences, Volume XIII, Fall 5(59), 1133-1142. 
3. Audretsch, D.B., Hülsbeck, M. \& Lehmann, E.E. (2012). Regional competitiveness, university spillovers, and entrepreneurial activity. Small Business Economics, 39(3), 587-601. doi:10.1007/s11187-011-9332-9.

4. Cammarano, A., Caputo, M., Lamberti, E., \& Michelino, F. (2017). Open innovation and intellectual property: a knowledge-based approach. Management Decision, 55(6), 1182-1208. doi:org/10.1108/MD-03-2016-0203.

5. Cavusgil, S.T., Knight, G., \& Uner, M.M. (2011). Born global firms in Turkey. Ankara, Turkey: Detay Yayincilik (Published in Turkish). Türkiye'de Küresel Doğan İşletmeler.

6. Connell, J., \& Voola, R. (2013). Knowledge integration and competitiveness: a longitudinal study of an industry cluster. Journal of Knowledge Management, 17(2), 208-225. https://doi.org/10.1108/13673271311315178.

7. Freeman, S., Hutchings, K., Lazaris, M., \& Zyngier, S. (2010). A model of rapid knowledge development: The smaller born-global firm. International Business Review, 19(1), 70-84. Doi:10.1016/j.ibusrev.2009.09.004.

8. Gellynck, X., Kuhne, B., \& Weaver, R.D. (2010). Relationship quality and innovation capacity of chains: The case of the traditional food sector in the EU. In M. Fritz, U. Rickert, \& G. Schiefer (Eds.). Proceedings of the 4th International European Forum on System Dynamics and Innovation in Food Networks: 352-373. Germany.

9. Gorlevskaya, L., Kubičková, V, Fodranová, I., Žák, Š. (2018). Innovations and New Product Development: Evidence from Enterprises Active in Slovak Republic. Journal of Applied Economic Sciences, Volume XIII, Spring, 1(55), 164 - 173.

10. Greve, H.R. (2007). Exploration and exploitation in product innovation. Industrial and Corporate Change, 16 (5), 945-975. doi;org/10.1093/icc/dtm013.

11. Grillo F., \& Landabaso, M. (2011). Merits, problems and paradoxes of regional innovation policies. Local economy, 26(6-7), 544-561. doi.org/10.1177/ 0269094211417161.

12. Huang, C., Arundel, A., \& Hollanders, H. (2010). How firms innovate: R\&D, non R\&D and technology adoption. The UNUMERIT Working Paper Series, 27.

13. Hudáková, J., Fil'a, M., \& Maroš, M. (2017). Innovation potential of the regions in the Slovak Republic, Acta Oeconomica Universitatis Selye, 6(2), 81-88.

14. Karatepe, O,M., Uner, M.M., \& Kocak, A. (2016). Investigating the Impact of Customer Orientation on Innovativeness: Evidence from Born-G lobal Firms in Turkey. Economic Research-Ekonomska Istrazivanja, 29(1), 721-734. doi: 10.1080/1331677X.2016.1197548.

15. Kaufmann, H.R., Tsangari, H., \& Vrontis, D. (2012). Innovativeness of European SMEs: mission not yet accomplished. Ekonomska Istrazivanja - Economic Research, 25(1), 51-72, doi: 10.1016/j.technovation.2009.04.00.

16. Kim, D., Basu, C., Naidu, G.M., \& Cavusgil, E. (2011). The innovativeness of BornGlobals and customer orientation: Learning from Indian Born-Globals. Journal of Business Research, 64(8), 879-886. doi:org/10.1016/j.jbusres.2010.09.008.

17. Kitson, M., Martin, R., \& Tyler, P. (2004). Regional competitiveness: an elusive yet key concept?. Regional studies, 38(9), 991-999. doi: 10.1080/0034340042000320816.

18. Klein, L.R. (1962). An introduction to econometrics. Englewood Cliffs, NJ: Prentice-Hall.

19. Koval'ová, M., Hvolková, L., Klement, L., \& Klementová, V. (2018). Innovation strategies in the Slovak enterprises. Acta Oeconomica Universitatis Selye, 7(1), 7989.

20. Kwiek, M. (2012). Universities, regional development and economic competitiveness: The Polish case. In: R. Pinheiro, P. Benneworth and G. A. Jones (red). Universities and Regional Development. A Critical Assessment of Tensions and Contradictions: 69-85. New York: Routledge. 
21. Labunska, S., Petrova, M., \& Prokopishyna, O. (2017). Asset and cost management for innovation activity. Economic Annals-XXI, 165(5-6), 13-18. doi: 10.21003/ ea.V165-03.

22. Lee, S.M., Olson, D.L., \& Trimi, S. (2012). Co-innovation: convergenomics, collaboration, and co-creation for organizational values. Management Decision, 50(5), 817-831. doi:org/10.1108/00251741211227528.

23. Lundvall, B.A. (2010). National systems of innovation: towards a theory of innovation and interactive learning. London: Anthem Press. ISBN 9781843318668.

24. Maddala, G.S. (2001). Introduction to Econometrics. John Wiley \& Sons, Ltd, New York, 333.

25. Melén, S., \& Nordman, E.R. (2009). The internationalisation modes of Born Globals: A longitudinal study. European Management Journal, 27(4), 243-254. doi:10.1016/j.emj.2008.11.004.

26. Pianta, M. (2001). Innovation, Demand and Employment. Technology and the Future of European Employment. Edited by Pscal Petit and Luc Soete. Edward Elgar, Cheltenham, UK, Northampton, MA USA, 143.

27. Prokop, V., Stejskal, J., \& Kuvíková, H. (2017). The Different Drivers of Innovation Activities in European Countries: A Comparative Study of Czech, Slovak, and Hungarian Manufacturing Firms. Ekonomický časopis -Journal of Economics, 65(1), 31-45.

28. Skokan, K. (2010). Innovation Paradox and Regional Innovation Strategies. Journal of Competitiveness, 2(2), 30-46. http:/ / www.cjournal.cz/files/32.pdf.

29. Snieška, V., \& Bruneckienė, J. (2009). Measurement of Lithuanian regions by regional competitiveness index. Inzinerine Ekonomika- Engineering economics, 61(1), 45-57.

30. Solow, R. (1956). A Contribution to the Theory of Economic Growth, Quarterly Journal of Economics 70 (1), 65-94. http:/ / piketty.pse.ens.fr/files/Solow1956.pdf .

31. Stejskal, J., \& Hajek, P. (2015). Modelling Knowledge Spillover Effects Using Moderated and Mediation Analysis - The Case of Czech High-Tech Industries. In International Conference on Knowledge Management in Organizations: 329-341. Springer, Cham.

32. Stojčić, N., Hashi, I., \& Aralica, Z. (2018). Creativity, innovations and firm performance in an emerging transition economy. Ekonomski Pregled, 69(3), 203228.

33. Thomke, S., \& von Hippel, E. (2002). Customers as Innovators. A New Way to Create Value. Harvard Business Reviev, 80(4), 74-81. https://hbr.org/2002/04/ customers-as-innovators-a-new-way-to-create-value.

34. Tlesova, A., Mergaliyeva, L., Sultanguzhiyeva, A., \& Sharafutdinova, A. (2018). Improvement of innovative economic policy. Journal of Applied Economic Sciences, Volume XIII, Fall 6(60), 1654-1667.

\section{Correspondence address:}

Prof. Dr. Hab. Eng. Jan Zwolak, Faculty of Economies and Finance, Kazimierz Pulaski University of Technology and Humanities in Radom, 26-600 Radom, ul. Chrobrego 31, Poland. e-mails: jan.zwolak@yahoo.com; j.zwolak@uthrad.pl 